\title{
An Analysis of Anaphora and Cataphora in Muhsen Jabbar's Selected Stories
}

\author{
Maspufah $^{1}$, Afifah $^{2}$ \\ ${ }^{1}$ Akademi Bahasa Asing Persada Bunda \\ Email: maspufah81@gmail.com \\ ${ }^{2}$ Sekolah Tinggi Ilmu Bahasa Asing Persada Bunda \\ Email: afifaheljufryy@gmail.com
}

\begin{abstract}
The term dhaamir in Arabic means pronoun which function to replace things or people which refer forward or backward in the text. This study was intended to describe Arabic personal pronoun in short stories and classify it into anaphora and cataphora. This research was a descriptive qualitative research. The sources data of the research were three selected Arabic short stories written by Muhsen Jabbar which was published in 2013. Jabbar's short stories were selected because most of his works contained lessons of human attitude and behavior. After analyzing the data, the result showed that: (1) there were 152 anaphora found in Jabbar's short stories which consisted of 2 independent pronoun and 148 suffix personal pronoun. (2) There were 3 cataphora found in short stories. Thus, it could be concluded that anaphora was found more than cataphora in Muhsen Jabbar's selected short stories.
\end{abstract}

Keywords: Reference, Anaphora, Cataphora

\begin{abstract}
Abstrak
Istilah dhamiir dalam bahasa Arab berarti kata ganti yang berfungsi untuk mengganti benda atau orang yang mengacu kedepan atau kebelakang teks. Penelitian ini bertujuan mendeskripsikan kata ganti orang dalam bahasa Arab dalam cerita pendek dan mengelompokannya ke dalam anaphora dan cataphora. Penelitian ini merupakan penelitian dekriptif kualitatif. Sumber data penelitian ini adalah tiga cerita pendek berbahasa Arab karya Muhsen Jabbar yang terbit pada tahun 2013. Cerita pendek karya Jabbar dipilih karena karyanya sebagian besar berisi pelajaran tentang sikap dan tingkah laku manusia. Setelah menganalisis data, hasil penelitian ini menunjukkan bahwa: (1) 152 anaphora ditemukan dalam cerita pendek karya Muhsen Jabbar yang terdiri dari 4 independent pronoun dan 148 suffix personal pronoun. (2) Hanya 3 cataphora ditemukan dalam cerita pendek karya Muhsen Jabbar. Dengan demikian dapat disimpulkan bahwa anaphora ditemukan lebih banyak dibanding cataphora dalam cerita pendek yang ditulis oleh Muhsen Jabbar.
\end{abstract}

Kata Kunci: Reference, Anaphora, Cataphora

\section{INTRODUCTION}

Arabic as one of official United Nation language is widely spoken around the world. It is a primary language in Middle
East Asia and Africa. People learn and use the language as the medium of communication in both of spoken and written language. In written language, most of them expressed their thought into a 
literature work. It can be in the form of prose, poetry, fiction, and non- fiction literature.

Short story is one of fiction literature. According to Poe (cited in Ceylan, 2016:313) short story is a kind of narrative prose which can be read at one sitting of from one-half hour to two hours. It means that short story is shorter than novel. It usually contains only a few characters. One of famous short stories writer in Arabic is Muhsen Jabbar. Most of his short stories contained lessons of human attitude and behavior. The stories were interesting to read because the language used was easy to understand. However, the dhaamir in Arabic is complicated as it changes differently on personal pronoun.

The term dhaamir in Arabic means pronoun which have function to replace things or people. Pronoun in Arabic is more complicated because it is categorized in big number. The number of categories of personal pronoun in Arabic larger than in English because it includes many kinds of categories such as feminine and masculine forms, also the forms of the first, the second and the third person, than singular, dual and plural forms (Ryding, 2005:298).

In Arabic, personal pronoun was divided into two groups. The first group is independent personal pronouns رئامضل الا رد ذف صد لة;

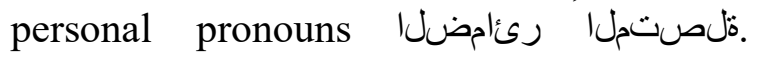
According to Pamungkas cited in Ngalim (2017) dhamir in Arabic categorized into two kinds: dhamir rafa' and dhamir nashab. Dhamir rafa' is a word which has functioned as subject and it is independent. Dhamir nashab is a word which has function as an object and dependent or attached to other words such as verb, noun and preposition.
Independent personal pronoun consisted information of persons, gender, and number markers. The form of suffix personal pronoun can be seen when it attaches to nouns, prepositions or verbs (Chacra: 2007). There are two sets of suffix pronoun. One set indicates possession or possessive pronoun when it attaches to the noun. The other set indicates object of a verb or object of a preposition when they attach to transitive verbs and preposition. Although possessive pronoun and object pronoun are used differently in Arabic, but their meaning and form are similar. The suffix personal pronoun for the first person singular ي.-ii/ when it attaches to a verb, it changes become ين/nii/ which indicate direct or indirect object of transitive verbs.

The pronoun position in Arabic can be referred forward or backward in the text. However, there is no specific term for it. Based on the comparative analysis, the pronoun in Arabic also can be categorized as cataphora and anaphora borrowing Halliday and Hasan term (cited in Maspufah 2018:33) Cataphora is a word or phrase which its entity refers forward in the text. While, anaphora refers back for its interpretation.

In English, cataphora and anaphora are parts of reference. Anaphora and cataphora are classified based on its position in the text (Cutting, 2002:9). Reference is a term for a word or phrase which related to its entity for its interpretation (Fromkin, Rodman, and Hymes, 2011:194). Yule (2003:204) asserts that reference is the relationship between expression in a text and expressions in different parts of the text. It means that reference's entity can be within a text or text to text. From the statements, it can be summed up that reference is a word or phrase which should 
be related to its entity within a text or text to text to get its interpretation.

Since this research analyzed dhaamir or pronoun, it means that the research discussed personal pronoun only. According to Halliday and Hasan (cited in Maspufah, 2018:34) Personal reference is the reference that exists in the speech situation in which occured in the form of personal pronoun, possessive determiner/ possessive adjectives, and possessive pronoun. They are also divided into singular and plural. Personal reference consists of the first person singular (I, me, my, mine), the first person plural (we, us, our, ours), the third person singular ( he, him, his, she, her, hers), the third person plural ( they, them, their, and theirs), and generalized human (one, one's)

Based on the previous explanation, the purpose of this research was to find out cataphora and anaphora from selected short stories written by Muhsen Jabbar which was published in 2013.

\section{METHOD}

This research was descriptive qualitative research which intended to describe Arabic personal pronoun in short stories and classify it into cataphora and anaphora. The sources data of the research were three selected Arabic short stories written by Muhsen Jabbar which was published in 2013. The data were collected from Muhsen Jabbar's book which published in 2013. The book is one edition which consisted several stories. The stories were selected based on the most interesting category.

The data were analyzed qualitatively through several steps. First, the stories were read and the pronouns used were identified. Second, the sentences which contained pronoun were underlined and highlighted.
Third, the pronouns were classified into cataphora and anaphora. The data were displayed in a table to see the number of cataphora and anaphora found from the story.

\section{FINDING AND DISCUSSION}

The data were analyzed to find anaphora and cataphora in three selected short stories by Muhsen Jabbar (2013). The data were presented in tabel 1 below:

Table 1. Anaphora and Cataphora in Muhsen Jabbar's Short Stories

\begin{tabular}{|c|c|c|c|}
\hline Title & $\begin{array}{c}\text { Types of personal } \\
\text { pronoun }\end{array}$ & Anaphora & Cataphora \\
\hline \multirow[t]{2}{*}{$\begin{array}{l}\text { Ajmalu } \\
\text { Ghurfatin } \\
\text { fil Baiti }\end{array}$} & $\begin{array}{c}\text { Independent } \\
\text { (damaa'ir } \\
\text { munfaSila) }\end{array}$ & 2 & \\
\hline & $\begin{array}{c}\text { Suffix } \\
\text { (damaa'ir muttaSila) }\end{array}$ & 52 & 1 \\
\hline \multirow{2}{*}{$\begin{array}{l}\text { Man Laa } \\
\text { Yasykuru } \\
\text { n Naasa } \\
\text { laa } \\
\text { Yasykuru } \\
1 \text { laaha, }\end{array}$} & $\begin{array}{l}\text { Independent } \\
\text { (damaa'ir } \\
\text { munfaSila) }\end{array}$ & - & \\
\hline & $\begin{array}{c}\text { Suffix } \\
\text { (damaa'ir muttaSila) }\end{array}$ & 45 & \\
\hline \multirow{2}{*}{$\begin{array}{l}\text { Malaku } \\
\text { wal } \\
\text { Jaziiratun } \\
\text { Naaiyatu }\end{array}$} & $\begin{array}{l}\text { Independent } \\
\text { (damaa'ir } \\
\text { munfaSila) }\end{array}$ & 2 & \\
\hline & $\begin{array}{c}\text { Suffix } \\
\text { (damaa'ir muttaSila) }\end{array}$ & 51 & 2 \\
\hline & TOTAL & 152 & 3 \\
\hline
\end{tabular}

From the table, it could be seen that anaphora was found more than the cataphora. In term of anaphora, suffixes personal pronoun were dominantly found from the short stories.

\subsection{Anaphora}

There were 54 anaphora found in the first short story entitled Ajmalu Ghurfatin fil 
Baiti. The followings were the description of anaphora in the short story:

\subsubsection{Independent Pronoun (damaa'ir munfaSila)}

a. إني أختار أجمل الغرف التي سنعيش بها أنا و أنت

Innii akhtaaru ajmalal ghurafi allati sana'iisyu biha ana wa anta

"I choose the nicest rooms where we will live I and you."

1. Ana is independent personal pronoun for the first person male or female singular. It refers to the mother. The word ana (أنا) appeared after the word mother (الأم) It was found in the first paragraph in the sentence jalasatil ummu zaa masaain as an answer for her husband question and it refers to herself.

2. Anta is independent personal pronoun for the second person male singular. It refers to the husband. The word anta (أنت) as appeared after the word "male". It was the mother's answer for her husband question and it refers to the husband (زوج)

Finding reference in Arabic independent personal pronoun can be regarded to be easier because the entity for its reference is very specific. The use of personal pronoun for gender such as male and female are different. Besides that, the personal pronoun for the first, the second, and the third are also identified by the number, such as singular, dual, or plural (Ryding, 2005:298).

\subsubsection{Suffix Personal Pronoun (damaa'ir muttaSila)}

a. جلست الأم ذا مساء تساعد أبنائها في مراجعة دروسيه

Jalasatil ummu zaa masaain tusa'idu abnaaahaa fi muraja'ati durusihim

"The mother sat in the evening helping her children in the review their lesson"

1. $\underline{\text { haa }}$ is suffix possessive pronoun for third person female singular which was attached to noun. It refers to the mother. The word -haa appeared after word the "her" (الأم).

2. - $\underline{\text { him }}$ is suffix possessive pronoun for the third person male plural which was attached to noun. It refers to the children. The word -him appeared after the word the children abnaaaha.

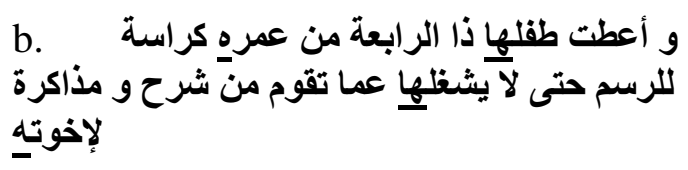

wa a'that tiflahaa assaghira zar raabi'ati min 'umrihi kurrasatan lirrasmi hatta la yusyghiluha amma taquumu bihi min syarhin wa muzakaratin li ikhwatihi.

"She gave her four years old child a book for painting so as not to distract her from explaining and studying his brothers."

1. $\underline{-h a a}$ is suffix possessive pronoun for the third person female singular which was attached to the noun. It refers to the mother. The word -haa appeared after the word "mother" (الأم).

2. $\underline{-h i}$ is suffix possessive pronoun for the third person male singular which was attached to noun. It refers to the kid. The word - $h i$ appeared after word "the kid" (الطقل). 
3. -haa is suffix object pronoun for third person female singular which was attached to verb. It refers to the mother. The word -haa appeared after word “mother (الأم).

4. $\underline{-h i}$ is possessive pronouns suffixes for third person male singular which was attached to noun. It refers to the kid. The word -hi appeared after word "the kid" (الطفل).

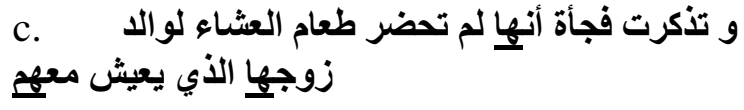

wa tazakkarat fajatan annahaa lam tahdhur tha'aamal 'asyaai li walidi zauji haa.

"Suddenly, she remembered that she did not attend dinner for her husband's father who lived with them."

1. $\underline{-h a a}$ is suffix object pronoun for the third person female singular which was attached to preposition. It refers to the mother. The word -haa appeared after the word "mother" (الأم).

2. $\underline{-h a}$ is suffix possessive pronoun for the third person female singular which was attached to noun. It refers to the mother. The word -haa appeared after the word "mother" (الأم).

3. - hum is suffix object pronoun for the third person male plural which was attached to preposition. It refers to the mother, children and husband. The word -hum appeared after the word "mother (الأم) , أبنآء) and husband" (زوج).

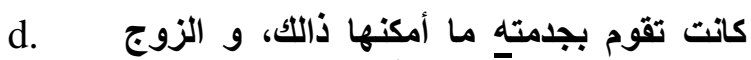

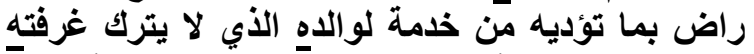

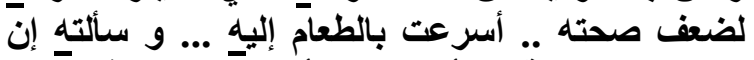
كان بحاجة إلى أي خدمات أخرى ثَثم انصرفت عَنهـه. kaanat taquumu bi khidmatihi maa amkanahaa zaalika, waz zauju raadhin bimaa tuaddi min khidmatin li waalidihi allazi la yatruku ghurfatahu li dha'fi shihhatihi.. Asra'at bit ta'ami ilaihi .. wa saalathu in kaana bihaajatin ila ayyi khadamaatin ukhro summa insharafat 'anhu.

"she was doing service him, and the husband was satisfied with the service she did for his father who did not leave his room due he is unwell. She rush with food to him, she asked him if he needed any aother services and then she left him".

1. $\underline{-h i}$ is suffix possessive pronoun for the third person male singular which was attached to noun. It refers to the father in law. The word $-h i$ appeared after the word "father in law" (والد زوجها).

2. $\underline{-h i}$ is suffix possessive pronoun for the third person male singular which was attached to noun. It refers to the husband. The word -hi appeared after the word "husband" (زوج).

3. $-\underline{h u}$ is suffix possessive pronoun for the third person male singular which was attached to noun. It refers to his father. The word $-h u$ appeared after the word "his father" (والده).

4. $\underline{-h i}$ is suffix possessive pronoun for the third person male singular which was attached to noun. It refers to his father. The word $-h i$ appeared after the word "his father" (والده).

5. $\underline{-h i}$ is suffix object pronoun for the third person male singular which was attached to preposition. It refers to the father in law. The word - $h i$ appeared after the word "father in law" (روالد (زوجها). 
6. $\underline{-h u}$ is suffix object pronoun for the third person male singular which was attached to verb. It refers to the father in law. The word -hi appeared after the word "father in law" (والد زوجها).

7. $\underline{-h u}$ is suffix object pronoun for the third person male singular which was attached to the preposition. It refers to the father in law. The word $-h u$ cames والد ( after the word "father in law" (زوجه).

It can be concluded that there were 152 anaphora found in the short stories which was consisted of 4 independent personal pronoun and 148 suffix personal reference.

Finding reference in suffix pronoun includes some complicated process, such as identifying the personal pronoun which includes information of persons, gender, and number markers. Then, indicating the form. When suffix personal pronoun attaches to a noun, its form to be possessive pronoun. When it attaches to intransitive verb, its form to be object of a verb, and when it attaches to preposition, its form to be object of preposition. Even it is a complicated process, for learners who had mastering Arabic well; the suffix pronoun can be used as clue for its reference entity. The uniqueness and the information about the suffix pronoun had locked information about its entity because the form of suffix personal pronoun can be seen when it attaches to nouns, prepositions or verbs (Chacra: 2007).

Both of independent pronoun and suffix pronoun in the three selected short stories were classified into anaphora because the reference refers back to text (Halliday and Hasan cited in Maspufah 2018: 33). It means that the information was presented prior to the entity. By understanding the uniqueness of Arabic personal pronoun, the reader would interpret the reference easily.

\subsection{Cataphora}

There was one cataphora only found in the first of short story Ajmalu Ghurfatin fil Baiti. The following is the description of cataphora in the first short story.

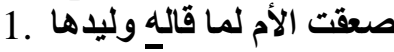

sha'iqatil ummu lima qaalahu waliiduha

"the mother shocked of her child said".

$\underline{-h u}$ is the suffix possessive pronoun for the third person male singular. It refers to her son. The word $-h u$ appeared before the word "her son".

There were two cataphora found in the second of short story Man Laa Yasykurun Naasa laa Yasykurul laaha. The followings were the description of cataphora in the second short story.

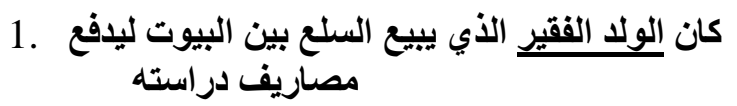

kaanal waladul faqiirul lazi yabii'us sil'a bainal buyuuti li yadfa'a mashaariifa diraasatih

"The poor boy who sold the goods between the houses to pay his studies".

al waladul faqiiru الولد الفقير in the first paragraph refers forward to one name in the second paragraph that is Hawarid Kylie

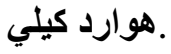

و عندما غادر هوارد كيلي المنزل

wa indama ghaadara Hawarid Kylie al manzila

"When Hawarid Kylie leave the home". 
شكرا لكِ يا إلهي2

syukran laka ya Ilahii

"thank you my God".

$-\underline{k a}$ is the suffix possessive pronoun for the second person male singular. It refers to my God that located after word $-k a$

There was not cataphora found in the third short story Al Malaku wal Jaziiratun Naaiyatu. It could be summed up that there were three cataphora found in three short stories by Muhsen Jabbar.

The suffix possessive pronoun which was found from the three selected short storied was classified into cataphora as its reference refers forward in the text (Halliday and Hasan, cited in Maspufah 2018:33). It means that the entity was stated prior to the information. It can be exist within the text or text to text. This kind of reference was regarded difficult for learners because they tent to find the entity after the information.

\section{CONCLUSION}

There were 152 anaphora reference found in the short stories which consisted of 4 independent personal pronoun and 148 suffixes personal pronoun. Cataphora reference were found 3 only. So, anaphora reference were found more than cataphora in the three selected short stories written by Muhsen Jabbar.

Since Arabic is one of official United Nation language, hopefully the result of this study motivate the reader to learn more about Arabic and Arabic literature.

\section{REFERENCES}

Ceylan, N.O. 2016. Using Short Stories in Reading Skills Class. Procedia - Social and Behavioral Sciences. Proceeding 232 p. $311-315$

https://www.researchgate.net/publication 1309329451_Using_Short_Stories_in_Re ading_Skills_Class

Chacra, Faruk Abu. 2007. Arabic An Essential Grammar. New York: Routledge.

Cutting, J. 2002. Pragmatics and Discourse. London : Routledge.

Fromkin, V, Rodman, R and Hyams, N. 2011 ( $^{\text {th }}$ edition). An Introduction to Language. Boston: Michael Rosenbery.

ع له تني ق صص .Jabbar, Muhsen. 2013 ال ح ياة. Syria: Dar al manahij

Maspufah, M. .2018. Analysis of EFL Learners' Competence in Using Anaphora Reference in reading Technical Text. ELT-Lectura, 5(2), 167173. https://doi.org/10.31849/eltlectura.v5i2.1677

Ngalim, Abdul. 2017. Comparison of Personal Pronoun between Arabic and Its Indonesian Translation of Korea. International Journal of Applied Linguistics \& English Literature. Volume 6 No. 5. 238-254 http://www.journals.aiac.org.au/index.ph p/IJALEL/article/view/3473

Ryding, Karin C. 2005. A Reference Grammar of Modern Standard Arabic. New York: Cambridge University Press.

Yule, G. 2003. Pragmatics. Oxford:Ox 